\title{
Mongols and the Silk Roads: an Overview
}

\author{
SZILVIA KOVÁCS ${ }^{1 *}$ AND MÁRTON VÉR ${ }^{2}$
}

\author{
${ }^{1}$ University of Szeged, Egyetem u. 2. 6722, Szeged, Hungary; Eötvös Loránd Research Network (ELKH) \\ ${ }^{2}$ Georg-August-Universität Göttingen, Heinrich-Düker-Weg 14, D-37073 Göttingen \\ E-mail: marton.ver@uni-goettingen.de
}

(c) 2021 The Authors

The volume at hand stands at the intersection of two recently booming fields of research into Central or Inner Eurasian history: the history of the Silk Roads and the Mongol Empire, both of which are enjoying the growing attention of a broader public. ${ }^{1}$ In order to highlight the scholarly context of this special issue of the Acta Orientalia Academiae Scientiarum Hungaricae (AOH), this introduction outlines the reasons behind this growing interest and current trends shaping the development of both fields. ${ }^{2}$

Central or Inner Eurasia is defined in this volume as the vast area between the lower Danube River region in the west and Manchuria in the east, between Iran and the Himalayas in the south and the taiga forest zone in the north. In this way, the Pontic-Caspian Steppe, West Turkestan (present-day Kazakhstan, Turkmenistan, Uzbekistan, Tajikistan, and Kyrgyzstan), Southern Central Asia (Afghanistan and north-eastern Iran), East Turkestan (Xinjiang), Tibet, the Eastern Steppe (Mongolia and Inner Mongolia) and Manchuria were all part of Central Eurasia (Beckwith 2009: xx). Many climates, landscapes, lifeways, languages, and religions have existed in these territories, periodically united within single empires, each of which provided the region with an economic-political unit. The rise, flourishing and disappearance of these empires occurred in

\footnotetext{
* Corresponding author. E-mail: kovacsszil@yahoo.com

1 Obvious signs of the growing attention to, and institutionalization of, both fields within the educational system are the recent publication of teaching materials in English (Amster 2005; Khan Academy, IDP) and in German (DAI). Moreover, the last year saw the release of the first edited volume on the Silk Roads in the Mongol period, a work aimed to facilitate university teaching alongside its contributions to the research community (Biran and Brack and Fiaschetti 2020).

2 Due to the immeasurable volume of new literature and the limits of this introduction, the following summary does not provide an exhaustive list of valuable scholarly publications, displaying only notable examples of the major trends. The selection of works cited is of course influenced by the authors' respective fields.
} 
parallel with the significance of the most famous and, from a cultural-historical aspect, the most significant, transcontinental trade system, known as the Silk Roads.

In 1877, the German geologist Ferdinand von Richthofen named this sprawling web of channels Seidenstraßen 'Silk Roads', using this term to describe the trade routes between China, Transoxiana (between the Syr Darya and Amu Darya Rivers) and India in the period of the Han dynasty (206 BCE - $220 \mathrm{CE}$ ), during which the most important merchandise, according to Richthofen, was silk (Richthofen 1877a: 454 ff; Richthofen 1877b: 96 ff). Recently, Mertens (2019) pointed out that the expression had been used earlier in the scholarly literature and Richthofen can be credited as one of those who helped to spread the word in the broader public. Sven Hedin, one of Richthofen's most famous pupils, described this network in his book: 'The whole Silk Road, from Sian [Xian] via Anhsi [Anxi], Kashgar, Samarkand and Seleucia to Tyre, is 4,200 miles as the crow flies and, including bends, something like 6,000 miles, equivalent to a quarter of length of the equator' (Hedin 1938: 228). Hedin also defined a 'Maritime Silk Road' as 'the sea route to India, Arabia, Egypt and the coast towns of the Mediterranean' (Hedin 1938: 226).

Scholarship over the last few decades has produced an unexpectedly rich literature on the Silk Roads, both scholarly and popular in nature. To understand this remarkable interest, we must consider the history of Silk Roads studies. In the history of scholarship, it is not unusual for growing political interest to prompt scholarly and scientific interest, but study of the Silk Roads is an outstanding example of this phenomenon. Even the birth of the Silk Road concept is strongly related to the Great Game, namely political and diplomatic confrontation between the British and Russian empires over a part of Central Eurasia in the $19^{\text {th }}$ and early $20^{\text {th }}$ century. ${ }^{3}$ This peculiarity of Silk Road studies can also be observed in later periods, as the initiation of major projects was closely associated with major political change. After the Second World War and in the middle of the Cold War, UNESCO launched a decade-long Orient-Occident Major Project (1957-1966) with the task of promoting the mutual appreciation of eastern and western cultural values. A second aim of the project was to encourage specialists to work together in common endeavours (Elisseeff: 2000: 12). Relating to the Silk Roads, a Japanese National Commission in October-November 1957 prepared a scientific program for studying three intercultural routes: the Steppe Route, the Oasis Route, and the Maritime Route. A few decades later, UNESCO launched a further ten-year project, Integral Study of the Silk Roads: Roads of Dialogue, between 1988 and 1997 (Elisseeff 2000, 12-14). This project, for which the main investigative theme was intercultural activity and resulted in the publication of the multi-volume History of Civilizations of Central Asia (1992-2005).

The dissolution of the Soviet Union in 1991 brought another heyday of the Silk Roads concept, as a new Great Game began with the participation of the newly born Central Asian states and great powers. Rail and road networks, construction of gas and oil pipelines, intercultural dialogue and research into the ancient Silk Roads network were all part of this process. The most recent trigger to boost Silk Roads studies is the Chinese government's 2013 Belt and Road Initiative (BRI). Beside political and economic attention, the initiative also sparked scholarly interest. These major political changes over the decades have brought Silk Roads studies to a new heyday.

To summarize recent trends in Silk Roads studies, four major clusters are distinguishable: the emergence of micro and macro approaches, the publication of local source materials, new approaches to the 'goods' transported on the Silk Roads, and finally an ever-growing interdiscipli-

\footnotetext{
3 This fact is mirrored in the first sentence of Richthofen's famous lecture, which credits the newest knowledge on Central Asia to the adventurousness of Russian and English travelers (Richthofen 1877b: 96).
} 
narity. Growing scholarly interest is shown very well by the evolvement and institutionalization of subfields like Turfan (Durkin-Meisterernst et al. 2004) and Dunhuang studies (Galambos 2020; Hao 2020). Interestingly, macro and micro approaches to the study of the Silk Roads have spread in parallel over the last few decades. On the one hand, the traditional view of the overland Silk Roads has broadened into neighbouring territories, with the Eurasian steppe region foremost (Christian 2000; Polgár 2019) along with the maritime Silk Roads (e.g. Jacq-Hergoualc'h 2001; Kauz 2010). This led to the interpretation of the Silk Roads in a world historical perspective (Liu 2010) and the fact that probably the most widely-known recent contribution (Frankopan 2015) even put the Silk Roads at the centre of a world historical narrative might be taken to mark a peak of the macro-historical approach. On the other hand, scholarship has clarified that no regular direct connections existed between the two endpoints of the commercial network (China and the Mediterranean region) in antiquity, i.e., before the $5^{\text {th }}$ century CE (e.g. Hoppál 2020) and thus the Silk Roads have recently come to be regarded rather as an intercontinental amalgam of numerous regional and interregional networks. Consequently, scholars have stressed the significance of local perspectives (Hitch 2009; Vaissière 2014) and the importance of local trade (Hansen 2017). An extreme end of this approach questioned the validity of the Silk Roads concept (Rezakhani 2010). Other micro-historical perspectives concentrated on stories of everyday life and of individuals, sometimes even imaginary ones (Felföldi 2001; Whitfield 2015). This advance of the local in historical literature is associated with the effects of the post-colonial discourse, and is inseparable from increasingly easy access to archives worldwide, i.e. the cataloguing, edition, and publication of local source materials. A comprehensive list of these would go beyond the limits of this introduction but perhaps this short and incomplete list of source publications from the last decade of documents concerning commerce will illustrate this trend: documents in Bactrian (Sims-Williams 2012), Tocharian (CEToM), Sogdian (Benkato 2018; Yoshida 2019), and Uyghur (Moriyasu 2019; Vér 2019; Matsui 2021) have all been published recently. ${ }^{4}$ Another clearly definable direction of recent scholarship on the Silk Roads is connected to the culture historical perspective. In the footsteps of Schafer's seminal work (1963), increasing scholarly attention paid to the various goods wandering along the Eurasian networks showed that many kinds of merchandise were transported, silk not necessarily being the most important (e.g. Bloom 2005). Beside traditional philological works, interdisciplinary approaches and the use of scientific methods have recently emerged (Spengler III 2019; Yang et al. 2019; Barbaix et al. 2020). Of course, the culture historical approach goes beyond the analysis of commercial connections, and exchanges of a cultural (e.g. Wood 2003; Russel-Smith 2005) and religious nature (Foltz 1999; Meinert 2016) have been valuable additions to these research topics. Research by the MTA-ELTE-SZTE Silk Road Research Group in Hungary can be connected to this movement (e.g. Dallos and Kósa 2018). Traffic in goods, faiths, ideas, and people was always dependent on powerplay and geopolitics. Among the different power factors of Eurasia, the age of the Mongol Empire, which ruled about a third of the Old World, can be considered a heyday of the Silk Roads, because it created a high degree of mobility throughout Eurasia, with people, ideas, and goods traversing vast geographical and cultural expanses.

\footnotetext{
${ }^{4}$ An essential precondition for the preparation of text editions is the cataloguing of archives. In this respect the Union Catalogue of Oriental Manuscripts in German Collections (KOHD) is an exemplary undertaking that allowed, among many other projects, the cataloguing of the Old Uyghur documents (Raschmann 2007; Raschmann 2009; Raschmann and Sertkaya 2016). The first catalogue volume of the Old Uyghur manuscripts and blockprints in the Serindia Collection of the Institute of Oriental Manuscripts of the Russian Academy of Sciences in St. Petersburg is scheduled for publication this year (Lundysheva and Turanskaya 2020).
} 
Like research on the Silk Roads, the study of the Mongol Empire has also undergone change and development during recent decades. These relate only in part to the inclusion of new primary sources, ${ }^{5}$ with more significance linked to alterations in scholarly approach. The two key characteristics of these changes can be described as the rise of new cultural history on the one hand, and, on the other, application of the so-called holistic perspective, i.e. the study of the Mongol Empire not only from local or regional perspectives, but in its entire Eurasian context (Morgan 2015). Here we must mention the works of Thomas T. Allsen, who can be credited both with changes in research approaches and a good deal of the development in research on the Mongol Empire. His proficiency in Chinese, Persian and Russian helped him to simultaneously analyse textual sources from the most important historiographical traditions and thus to analyse the history of Mongol Eurasia from a holistic perspective. These new approaches to the study of the Mongol Empire have brought forth plenty of new and formerly neglected topics. Perhaps the greatest attention has been devoted to cultural and religious exchange across Eurasia during the $13^{\text {th }}$ and $14^{\text {th }}$ centuries, but the closely related question of economic connections has enjoyed a similarly elevated interest among the scholarly community (Biran 2015). These new studies have fundamentally changed our image of the Mongols. Without understating the brutality and devastation of the Mongol conquests, their importance as the founders of political, economic, religious and cultural macro structures that led to an unprecedented level of cultural and economic exchange across Eurasia is increasingly stressed. The Mongols not only provided the frameworks for intercontinental exchange, but they facilitated and filtered the interactions, i.e. they acted as active agents. Moreover, research over the last thirty years has pointed out that many of the empire's administrative and political structures lived on in the early modern states of Eurasia, and that the effects of the cultural changes they caused are still felt today. In this sense, the Mongols actively participated in the transition of the 'Old World' into the modern age.

Despite our written sources' emphasis on conflict between nomads and sedentary people, peaceful connections and especially trade played a similarly pivotal role in these multi-layered relations (Noonan 2000; Stark 2015; Honeychurch 2015). The role of merchants in these peaceful relations was always important, moreover traders played a key role in the formation of nomadic empires, as formulated in the theory of pax nomadica, modelled on the well-known concept of pax romana (Pritsak 1988). ${ }^{6}$ The close cooperation between nomadic conquerors and their usually ethnically distinct merchant partners have been well attested since at least the First Türk Khaganate (552-ca. 630/659): nomadic conquerors (Türks, Uyghurs, Khazars etc.) secured the peace required for commercial relations, while their merchant partners (Sogdians, Jews, Arabs etc.) shared their profits from long-distance trade with the nomadic elite. Like many other aspects of Central Eurasian empire building, Mongol rule brought this cooperation to a new level: Chinggis Khan and his successors incorporated into their empire or drew into their sphere of influence vast territories of sedentary cultures with populations outnumbering them several times over, from East Asia through Central Asia and the Middle East right up to Eastern Europe. The Mongols soon came to recognise a need for literate, polyglot, and mobile servants, familiar with the customs and laws of the sedentary people. The possession of all these capabilities made mer-

${ }^{5}$ It should be noted, however, that many important sources have appeared in new editions and many have been translated into western languages. On progress in publishing primary sources see Jackson 2000: 190-191; Morgan 2007²: 182-185; Biran 2013: 1023-1024; Biran 2018.

6 The term pax mongolica evolved and later became widespread in scholarly literature. On the various criticisms concerning the usage of this term and an outline of the whole problematic, see Kim 2009: 15-18. 
chants with various backgrounds perfect agents for the transmission of the know-how required by their new masters in the empire's formative period. These factors led the Mongol rulers to adopt pro-commerce policies and recruit a large number of merchants to the Mongol administration, sometimes at very high ranks.

From our point of view, probably the most important change of the Mongol period $\left(13^{\text {th }}\right.$ $14^{\text {th }} \mathrm{cc}$.) when compared to earlier periods was that for the first and last time in the history of the Silk Roads, the networks were under the rule of one political entity, i.e. the Mongol Empire. Despite this moment of united empire (Yeke Mongyol Ulus) lasting only briefly in a world historical perspective, namely from the early $13^{\text {th }}$ century till the death of Möngke great khan (1259), its consequences shaped the history of the Silk Roads up to the end of the Mongol period and in certain respects even beyond that, and the united imperial framework contributed to this last heyday of the Silk Roads in several ways. First and of foremost importance the united empire could grant relatively stable and secure travel and commerce across vast Eurasian territories (Kim 2009; Favereau 2018). Although after the dissolution of the united empire internal clashes between different branches of the Mongol elite were more or less constant, no devastating full-scale wars like the conquest period or, later, the campaigns of Timur (r. 1370-1405), destroyed the flourishing interregional connections that had been established. These factors enabled the deservedly famous intercontinental journeys along the Silk Roads of such emblematic figures of this period as Ibn Battuta, Rabban Sauma, Wang Dayuan or Marco Polo. More importantly the early $14^{\text {th }}$ century merchants' handbook of Pegolotti Practica della mercatura ('The Practice of Commerce') shows that intercontinental connections were no longer exceptional, and that long-distance trade was practiced on a regular basis. Secondly, the unification of weights, measures and currency systems made commerce in the territories under Mongol rule smooth and calculable (Kuroda 2009; Matsui 2009). Thirdly, the introduction of the postal system (Mong.: jam) on a previously unseen scale and its facilities for the hauling of bulk goods (tergen jam 'wagon post') provided an unprecedented level of support to trade (Silverstein 2007). Lastly, the formation of a solvent Mongol aristocracy living in the steppe region but willing to pay for the fine goods produced by sedentary peoples, and, parallel to this, the establishment of several new urban centres on the steppes (Qaraqorum, Saray etc.) with populations exceeding local provisioning capabilities, resulted in the deeper involvement of these territories within Eurasian trade networks. Due to these factors gradual alterations occurred in the structure of commerce: the growing importance of bulk goods altered the composition of merchandise, increasing the share of actual long-distance trade in commercial activities along the Silk Roads (Allsen 1989).

As can be seen in the topics of the contributions to this issue, in recent decades researchers have dedicated more attention to the role of non-economic exchange along the Silk Roads in the Mongol period than ever before. The results of these studies are notable, as some of these intercultural exchanges shaped the history of Central Eurasia for hundreds of years, and some are still felt today. From a religious perspective the spread of Islam in Eastern Europe and in Central Asia and parallel to this the spread of Tibetan Buddhism on the Eastern territories of the Mongol Empire might be the most important (DeWeese 1994; Elverskog 2010). The forging and spread of bureaucratic traditions and institutions determined the administrative structures of Central Eurasian states centuries after the dawn of the Mongols (e.g. Allsen 2010), while cultural and scholarly exchange brought civilizations closer than ever before (Allsen 2001).

The present special issue of the $\mathrm{AOH}$ is the latest result of scholarly cooperation among a group of early career scholars researching medieval and early modern Eurasia. This international 
scholarly community meets on a yearly basis within the framework of the so-called Mongol Empire Spring Series (M.E.S.S.) workshops. The aim of this initiative is to apply a more elaborate approach to the study of Mongol Eurasia, by enabling dialogue and cooperation among scholars specializing in the various regions and languages that are key to understanding the Mongol Empire and its neighbours. Francesca Fiaschetti and Marie Favereau organized the first workshop (Diplomacy in the Age of Mongol Globalization) in Jerusalem in 2016 within the framework of the ERC Mobility, Empire and Cross-Cultural Contacts in Mongol Eurasia project. The next meeting took place in Sofia (Mongol Warfare between Steppe and Sown: Military, Social and Cultural Perspectives) in 2017, organized by Boriana Antonova and Konstantin Golev with the support of the Centre for Advanced Study Sofia. The most recent event of the series was held in Vienna in 2019 (Religions in Mongol Eurasia) and was organized by Francesca Fiaschetti and Bruno de Nicola.

The first publication connected to the M.E.S.S. is a special issue of the journal Eurasian Studies (Diplomacy in the Age of Mongol Globalization, No. 17, 2019) edited by Francesca Fiaschetti and publishing the proceedings of the first workshop in Jerusalem. The papers from the Sofia workshop will be published as an edited volume on Mongol warfare, while the materials of the Vienna workshop are planned to be published in the Central Asiatic Journal.

The articles of this $\mathrm{AOH}$ special issue evolved from contributions to the third international workshop (The Mongols and the Silk Roads) held in Szeged on May $10^{\text {th }}-11^{\text {th }}, 2018$. The event was organized by the guest editors of the issue and authors of this introduction: Szilvia Kovács and Márton Vér, in cooperation with Prof. István Zimonyi and supported by the MTA-ELTE-SZTE Silk Road Research Group and the University of Szeged. This modest and focused event enabled young scholars to introduce their research on various aspects of the Silk Roads, such as the dynamics at the western edges of the Mongol Empire, namely the 'Golden Horde' and its successors, eastern and western Central Asia under Mongol rule, the overland and maritime Silk Roads, and EastWest intercultural exchange. ${ }^{7}$ The keynote speech, 'The Mongol Period: Heyday of the Silk Roads' was presented by Prof. István Vásáry (Eötvös Loránd University, Hungarian Academy of Sciences).

Unlike the outstanding edited volume published recently on the same topic (Biran, Brack and Fiaschetti 2020), due to its different format, the current special issue does not seek to give a comprehensive overview of the Silk Roads under Mongol rule and thus important current research topics such as the role of Mongol khatuns in commerce (Kovács 2020), maritime Silk Roads (Fiaschetti 2020) or religious exchange (Brack 2020) are not handled here. The articles in this volume, in accordance with the credo of $\mathrm{AOH}$, are based on the philological analysis of primary (mainly oriental) sources, and they scrutinize subjects connected to one or more of the current research trends outlined in this introduction. Taken together the contributions cover most of the Mongol Empire geographically, along with the main regions of the overland Silk Roads, while considering the centuries both preceding and succeeding the Mongol period. Konstantin Golev's voluminous article gives a detailed analysis of the cohabitation and shifting power balance between the Cuman-Qïpchaq nomads and the Anushteginids of Khwarezm in Central Asia, with a special focus on the region along the Syr Darya including the cities of Jand and Sïghnaq between the $11^{\text {th }}$ and early $13^{\text {th }}$ centuries. István Zimonyi uses an interdisciplinary approach to identify the city of Men Kermen attested in the Secret History of the Mongols reports on the Mongols' western campaigns, showing how the epic chronicle mirrors the decision makers'strategic thinking. Yoichi Isahaya's article contributes to the study of intercultural connections between Persia and China

7 http://alt.u-szeged.hu/index.php/abstracts-final/ (last accessed: 19.02.2021). 
along the Silk Roads. The author reconstructs a hitherto unknown transmission route of astral sciences through the story of an armillary sphere dedicated by Jamāl al-Dìn to Qubilai, showing how intercultural exchange was determined by personal connections. Márton Vér introduces the socio-economic role of viniculture in the Uyghur society of the Turfan region between the $9^{\text {th }}$ and $14^{\text {th }}$ centuries, with a special focus on the Mongol period, highlighting a growing interest among the nobility in wine production and the institutionalization of vinicultural assets during the Mongol period. The author argues that these processes mirror changes in transportation and Eurasian interregional contacts under Mongol rule. Csaba Göncöl scrutinizes the story of Bärdi Bäk khan in Ötämiš Hāăjȳìs Čingiz-nāmä, showing how the work operates with historical events and persons, preserving historical details while at the same time deploying fictional elements and motives to explain a plot. Qiu Yihao analyses Chinese sources from the Ming period (r. 1368-1644) concerning Timurid Central Asia, showing that Persian remained the lingua franca in $16^{\text {th }}$ century Eastern Eurasia and that the Ming court possessed up-to-date information on these regions.

We firmly believe that the papers in this volume, through their inclusion of previously neglected or barely used original sources, and through their analysis of complex historical processes, will contribute both to our understanding of the Silk Roads and of the Mongol Empire. Their diverse insights, illuminating issues such as the relationships between nomads and sedentary cultures, trade and scientific exchange, will lead to fruitful discussion in the future. By drawing together a variety of scholars in a single volume, we hope to have taken another step towards a new understanding of some of the more significant ways in which the study of medieval Central Eurasia and the Silk Roads has changed recently and will likely continue so to do.

We would like to thank István Vásáry, who offered the possibility of publishing the reviewed papers in this prestigious journal, as well as the anonymous reviewers, who helped sharpen the authors' arguments. Thanks are due to our editor-in-chief, Gábor Kósa, for his enthusiastic support since this volume's inception.

\section{REFERENCES}

Allsen, Thomas T. 1989. 'Mongol Princes and Their Merchant Partners.' Asia Major (Third Series) 2: 83-126. Allsen, Thomas T. 2001. Culture and Conquest in Mongol Eurasia. Cambridge: Cambridge University Press. Allsen, Thomas T. 2010. 'Imperial Posts, West, East and North: a Review Article'. Archivum Eurasiae Medii Aevi 17: 237-276.

Amster, Martin (ed.) 2005. From Silk to Oil: Cross-Cultural Connections Along the Silk Roads. New York: China Institute in America.

Barbaix, Sophie et al. 2020. 'The Use of Historical Sources in a Multi-Layered Methodology for Karez Research in Turpan, China.' Water History 12: 281-297.

Bескwiтн, I. Christopher 2009. Empires of the Silk Road. A History of Central Eurasia from the Bronze Age to the Present. Princeton and Oxford: Princeton University Press.

Benkato, Adam 2018. Studies on the Sogdian Epistolary Tradition. [Berliner Turfantexte 41] Turnhout: Brepols.

Biran, Michal 2013. 'The Mongol Empire: The State of the Field.' History Compass 11/11: 1021-1033.

Biran, Michal 2015. 'The Mongol Empire and Inter-Civilizational Exchange.' In: Benjamin Z. KedAR and Merrey E. Wiesner-Hanks (eds.) The Cambridge World History. Vol V.: Expanding Webs of Exchange and Conflict, 500 CE - 1500 CE. Cambridge: Cambridge University Press, 534-558. 
Biran, Michal 2018. 'Mobility, Empire and Cross-Cultural Contacts in Mongol Eurasia.' Medieval Worlds. Comparative \& Interdisciplinary Studies 8: 135-154.

Biran, Michal, Jonathan M. Brack and Francesca Fiaschetti (eds.) 2020. Along the Silk Roads in Mongol Eurasia: Generals, Merchants, Intellectuals. Oakland CA: University of California Press.

BLoom, Jonathan M. 2005. 'Silk Road or Paper Road?' Silk Road 3/2: 21-26.

BraCK, Johnatan 2020. 'Rashīd al-Dīn: Buddhism in Iran and the Mongol Silk Roads.' In: BIRAN and BraCK and FiAsCHETti 2020: 215-237.

Dallos, Edina and Gábor Kósa (eds.) 2018. Kultúrák találkozása és kölcsönhatása a Selyemút mentén: Ecsedy Ildikó születésének 80. évfordulójára [Meeting of Cultures Along the Silk Road. For the 80th Anniversary of the Birth of Ildikó Ecsedy]. Budapest: SZTE BTK Altajisztikai Tanszék, ELTE Távol-keleti Intézet.

DeWeEse, Devin 1994. Islamization and Native Religion in the Golden Horde: Baba Tükles and Conversion to Islam in Historical and Epic Tradition. University Park, PA: Pennsylvania State University Press.

Durkin-Meisterernst, Desmond et al. (eds.) 2004. Turfan Revisited: the First Century of Research into the Arts and Cultures of the Silk Road. Berlin: Dietrich Reimer Verlag.

Elisseeff, Vadime 2000. 'Approaches Old and New to the Silk Roads.' In: Vadime Elisseef (ed.) The Silk Roads: Highways of Culture and Commerce. New York and Oxford and Paris: Berghahn Books and UNESCO Publishing.

Elverskog, Johan 2010. Buddhism and Islam on the Silk Road. Philadelphia, PA: University of Pennsylvania Press.

Favereau, Marie 2018. 'The Mongol Peace and Global Medieval Eurasia.' Zeitschrift für Globalgeschichte und vergleichende Gesellschaftsforschung 28/4: 49-70.

FELFöLDI, Szabolcs 2001. 'A Prominent Hephthalite: Katulph and the Fall of the Hephthalite Empire.' AOH 54/2-3: 191-202.

Fiaschetti, Francesca 2020. 'Yang Tingbi: Mongol Expansion along the Maritime Silk Roads' In: Biran, Brack and Fiaschetti 2020: 83-101.

Foltz, Richard C. 1999. Religions of the Silk Road: Overland Trade and Cultural Exchange from Antiquity to the Fifteenth Century. New York: St. Martin's Press.

Frankopan, Peter 2015. The Silk Roads. A New History of the World. London and Oxford: Bloomsbury.

Galambos, Imre 2020. Dunhuang Manuscript Culture. [Studies in Manuscript Cultures 22.] Berlin and Boston: De Gruyter.

HaO, Chunwen 2020. Dunhuang Manuscripts: An Introduction of Texts from the Silk Road. [Trans. Stephen F. Teiser] Diamond Bar: Portico Publishing Company.

Hansen, Valerie 20172. The Silk Road. A New History. Oxford and New York: Oxford University Press.

Hedin, Sven 1938. The Silk Road. London: George Routledge and Sons.

Hiтch, Doug 2009. The Special Status of Turfan. [Sino-Platonic Papers 186.] Philadelphia: Department of East Asian Languages and Civilizations, University of Pennsylvania.

Honeychurch, William 2015. 'From Steppe Roads to Silk Roads. Inner Asian Nomads and Early Interregional Exchange.' In: Reuven Amitai and Michal Biran (eds.) Nomads as Agents of Cultural Change. The Mongols and Their Eurasian Predecessors. Honolulu: University of Hawai'i Press, 50-87.

HoppáL, Krisztina 2020. 'Rome, China and West-East Intercultural Communication in Antiquity: An Archaeological Perspective.' Studies on Cultures along the Silk Roads 2: 56-83.

Jackson, Peter 2000. 'The State of Research: The Mongol Empire, 1986-1999.' Journal of Medieval History 26: $189-210$.

JacQ-Hergoualc'H, Michel 2001. The Malay Peninsula Crossroads of the Maritime Silk Road (100 BC-1300 $A D)$. Leiden: Brill. 
KAUZ, Ralph (ed.) 2010. Aspects of the Maritime Silk Road: from the Persian Gulf to the East China Sea. Wiesbaden: Harrassowitz.

Kovács, Szilvia 2020. 'Taydula: A Golden Horde Queen and Patron of Christian Merchants.' In: BIRan, Brack and Fiaschetti 2020, 194-212.

Kuroda, Akinobu 2009. 'The Eurasian Silver Century, 1276-1359: Commensurability and Multiplicity' Journal of Global History 4/2: 245-269.

Liv, Xinru 2010. The Silk Road in World History. Oxford and New York: Oxford University Press.

Lundysheva, Olga and Anna Turanskaya 2020. 'Old Uyghur Fragments in the Serindia Collection: Provenance, Acquisiton, Processing.' Written Monuments of the Orient 6/2: 43-64.

Matsui, Dai 2009. 'Mongol Globalism Attested by the Uigur and Mongol Documents.' Studies in the Humanities (Volume of the Cultural Sciences) 22: 33-42.

Matsui, Dai 2021. Old Uigur Administrative Orders from Turfan. [Berliner Turfantexte 4X.] Turnhout: Brepols. (forthcoming).

Meinert, Carmen (ed.) 2016. Transfer of Buddhism Across Central Asian Networks ( $7^{\text {th }}$ to $13^{\text {th }}$ Centuries). Leiden: Brill.

Mertens, Matthias 2019. 'Did Richthofen Really coin “the Silk Road?”' The Silk Road 17: 1-9.

Morgan, David 2007². The Mongols. Oxford and Malden and Victoria: Blackwell Publishing.

Morgan, David 2015. 'Mongol Historiography since 1985: The Rise of Cultural History'. In: Reuven AmitaI and Michal Biran (eds.) Nomads as Agents of Cultural Change. The Mongols and Their Eurasian Predecessors. Honolulu: University of Hawai'i Press, 271-282.

Moriyasu, Takao 2019. Corpus of the Old Uighur Letters from the Eastern Silk Road. [Berliner Turfantexte 46.] Turnhout: Brepols.

Noonan, Thomas S. 2000. 'The Fur Road and the Silk Road: the Relations between Central Asia and Northern Russia in the Early Middle Ages.' In: Csanád BÁLint (ed.) Kontakte zwischen Iran, Byzanz und der Steppe im 6.-7. Jh. Budapest: Publicationes Instituti Archaeologici Academiae Scientiarum Hungaricae, 285-301.

Polgár, Szabolcs József 2019. ‘The Character of the Trade between the Nomads and their Settled Neighbours in Eurasia in the Middle Ages.' In: Hao CHen (ed.) Competing Narratives between Nomadic People and their Sedentary Neighbours. [Studia Uralo-altaica 53.] Szeged: University of Szeged, Department of Altaic Studies, 253-263.

Pritsak, Omeljan 1988. 'The Distinctive Features of the Pax nomadica.' In: Ovidio Capitani (ed.) Popoli delle steppe: Unni, Avari, Ungari; 23-29 aprile 1987. [Dettimane die Studio del Centro Italiani di Studi sull'alto medioevo XXXV] Spoleto: Presso la Sede del Centro, 749-780.

Raschmann, Simone-Christiane (ed.) 2007. Alttürkische Handschriften. Teil 13: Dokumente Teil 1. [Verzeichnis der Orientalischen Handschriften in Deutschland 13,21.] Stuttgart: Franz Steiner Verlag.

Raschmann, Simone-Christiane (ed.) 2009. Alttürkische Handschriften. Teil 14: Dokumente Teil 2. [Verzeichnis der Orientalischen Handschriften in Deutschland 13,22.] Stuttgart: Franz Steiner Verlag.

Raschmann, Simone-Christiane and Osman Fikri Sertkaya (eds.) 2016. Alttürkische Handschriften. Teil 20. Alttürkische Texte aus der Berliner Turfansammlung im Nachlass Reşid Rahmeti Arat. [Verzeichnis der Orientalischen Handschriften in Deutschland 13,28.] Stuttgart: Franz Steiner Verlag.

Rezakhani, Khodadad 2010. 'The Road That Never Was: The Silk Road and Trans-Eurasian Exchange.' Comparative Studies of South Asia, Africa and the Middle East 30/3: 420-433.

Richthofen, Ferdinand Freiherrn von 1877a. China. Ergebnisse eigener Reisen und darauf gegründeter Studien. Mit XXIX Holzschnitten und XI Karten. Bd. I. Berlin: Reimer.

Richthofen, Ferdinand Freiherrn von 1877b. 'Über die zentralasiatischen Seidenstrassen bis zum 2. Jh. n. Chr.' Verhandlungen der Gesellschaft für Erdkunde zu Berlin 4: 96-122. 
Russell-Smith, Lilla 2005. Uygur Patronage in Dunhuang: Regional Art Centres on the Northern Silk Road in the Tenth and Eleventh Centuries. [Brill's Inner Asian Library, vol. 14.] Leiden and Boston: Brill.

Schafer, Edward H. 1963. The Golden Peaches of Samarkand. A Study of T'ang exotics. Berkeley and Los Angeles: University of California Press.

Silverstein, Adam J. 2007. Postal Systems in the Pre-Modern Islamic World. Cambridge: Cambridge University Press.

Sims-Williams, Nicholas 2012. Bactrian Documents from Northern Afghanistan. I: Legal and Economic Documents. (Revised Edition). London: The Nour Foundation.

Spengler III, Robert N. 2019. Fruit from the Sands. The Silk Road Origins of the Foods We Eat. Oakland: University of California Press.

STARK, Sören 2015. 'Luxurious Necessities: Some Observations on Foreign Commodities and Nomadic Polities in Central Asia in the Sixth to Ninth Centuries.' In: Jan Bemmann and Michael Schmauder (eds.) Complexity of Interaction along the Eurasian Steppe Zone in the First Millenium CE. [Bonn Contributions to Asian Archaeology, Vol. 7.] Bonn: Universität Bonn Institut für Vor- und Frühgeschichtliche Archäologie, 463-502.

DE LA VAIssière, Étienne 2014. 'Trans-Asian Trade, or the Silk Road Deconstructed (Antiquity, Middle Ages).' In: Larry NeAL and Jeffrey G. Williamson (eds.) The Cambridge History of Capitalism. Volume I. The Rise of Capitalism: From Ancient Origins to 1848. Cambridge: Cambridge University Press, 101-124.

Vér Márton 2019. Old Uyghur Documents concerning the Postal System of the Mongol Empire. [Berliner Turfantexte 43.] Turnhout: Brepols.

Whitfield, Susan $2015^{2}$. Life along the Silk Road. London: John Murray.

Wood, Frances 2003. The Silk Road: Two Thousand Years in the Heart of Asia. London: British Library.

YANG, Liang Emlyn et al. (eds.) 2019. Socio-Environmental Dynamics along the Historical Silk Road. Cham: Springer.

YoshIDA, Yutaka 2019. Three Manichaean Sogdian Letters unearthed in Bäzäklik, Turfan. Kyoto: Rinsen Book Co.

\section{Online sources}

DAI: https://www.dainst.blog/bridging-eurasia/unterrichtsmaterial-zur-ostasiatischen-archaeologie/ (last accessed: 19.02.2021)

IDP: International Dunhuang Project: Education: http://idp.bl.uk/pages/education.a4d (last accessed: 17.02.2021)

Khan Academy: Transregional Trade: the Silk Road: https://www.khanacademy.org/humanities/worldhistory/ancient-medieval/silk-road/a/the-silk-road (last accessed: 17.02.2021)

KOHD: Union Catalogue of Oriental Manuscripts in German Collections: https://adw-goe.de/en/research/ research-projects-within-the-academies-programme/kohd/ (last accessed: 17.02.2021)

CEToM: A Comprehensive Edition of Tocharian Manuscripts: https://www.univie.ac.at/tocharian/?search (last accessed: 17.02.2021)

Open Access. This is an open-access article distributed under the terms of the Creative Commons Attribution 4.0 International License (https://creativecommons.org/licenses/by/4.0/), which permits unrestricted use, distribution, and reproduction in any medium, provided the original author and source are credited, a link to the CC License is provided, and changes - if any - are indicated. (SID_1) 